\title{
3D-MOLECULAR SCREENING OF DIKETOPIPERAZINE DERIVATES ON Staphylococcus aureus DEHYDROSQUALENE SYNTHASE USING VINA ${ }^{1}$
}

\author{
Broto Santoso \\ Faculty of Pharmacy, Muhammadiyah University of Surakarta \\ broto.santoso@gmail.com
}

\begin{abstract}
Dehydrosqualene synthase enzyme has been used as protein target model for exploring docking simulation of pyrazoline analogues. One of diketopiperazine derivates that have similar structure to pyrazoline has antibacterial activity against Staphylococcus aureus (S. aureus). Vina is AutoDock- improved program that capable for molecular screening based on free-energy and binding conformation prediction between ligand and protein target. The aim of these studies is to screen diketopiperazine derivates on dehydrosqualene synthase of $S$. aureus using Vina. Diketopiperazine derivates, curcumin analogues, curcumin, pentagammavunon derivates (PGV-0 and PGV-1) were calculated for their geometry optimization energy using Gaussian-Density Functional Theory method. 3D-optimized ligands along with reference ligands were screened for their binding energy with dehydrosqualene synthase (2ZCO) by docking using Vina. The lowest values of binding energy were analyzed with statistic method. The results showed that top thirteen ligands of docking binding energy with receptor are diketopiperazine derivates (31\%), curcumin analogues (31\%), and reference ligands (38\%). The new compounds of diketopiperazine derivates and curcumin analogues have better potency of binding energy than curcurmin as lead compound.
\end{abstract}

Keywords: diketopiperazine, Vina, docking, Staphylococcus aureus, curcumin.

\section{ABSTRAK}

Enzim dehidroskualen sintase telah digunakan sebagai protein target untuk eksplorasi simulasi docking analog pirazolon. Salah satu turuna diketopiperazin yang memiliki kemiripan struktur dengan pirazolon mempunyai aktivitas antibakteri terhadap Staphylococcus aureus (S. aureus). Vina merupakan program AutoDock yang disempurnakan untuk molecular docking yang mampu melakukan skrining molekul berdasarkan prediksi energi bebas dan konformasi ikatan antara ligan dan protein. Penelitian ini bertujuan untuk mencari turunan diketopiperazin yang berinteraksi kuat dengan dehidroskualen sintase S. aureus menggunakan Vina. Turunan diketopiperazin, analog kurkumin, kurkumin, turuna pentagammavunon (PGV-O dan PGV-1) dilakukan optimasi geometri menggunakan metode Gaussian-Density Functional Theory. Molekul hasil optimasi bersama dengan ligan pembanding dilakukan skrining energi ikatan dengan dehidroskualen sintase (2ZCO) melalui docking menggunakan Vina. Energi ikatan terendah yang diperoleh dianalisis dengan metode statistik. Hasil menunjukkan bahwa 13 terbesar untuk energi ikatan memiliki distribusi sebagai berikut turunan diketopiperazin (31\%), analog kurkumin (31\%), dan ligan pembanding (38\%). Molekul baru turunan diketopiperazin yang juga merupakan analog kurkumin mempunyai potensi energi ikatan yang lebih baik dibandingkan kurkumin sebagai senyawa penuntunnya.

Kata Kunci : diketopiperazine, Vina, docking, Staphylococcus aureus, kurkumin.

\footnotetext{
The article has been presented at International Seminar on Medicinal Chemistry and Timmerman Award 2011, Faculty of Pharmacy, Airlangga University. Surabaya. 15 October 2011.
}

\section{INTRODUCTION}

Infection disease in Indonesia is not show a decrease number of incidence. Otherwise, we must face an increased incidence of bacterial resistance to the drugs on the market recently. This serious health threat is the result of an acceleration of the development of bacterial strains that are resistant to antibacterial agents. Post operative (usually in hospital) and community-acquired infections is caused by Staphylococcus aureus bacteria. Methicillin-resistant Staphylococcus aureus could produces staphyloxanthin as a virulence factor. It promotes resistance to reactive oxygen species (such as superoxide, peroxide, and hypochlorite) and host neutrophilbased killing that are produced during the inflammatory response. Staphylococcus aureus dehydrosqualene synthase has been studied as protein that responsible for bacterial survival 
during infections. Crystal structure of dehydrosqualene synthase enzyme has been studied as protein model for previous molecular docking screening of ligand-receptor (Bhatia et al, 2010; Parameshwar et al, 2009). One of diketopiperazine derivates that have similar structure to pyrazoline has antibacterial activity against Staphylococcus aureus ( $S$. aureus).

Several diketopiperazine derivates are analogous compounds of curcumin as lead compound. Derivates and analogues compound of curcumin have been developed and studied. Curcumin has very weak antibacterial activity. Its activity is influenced by functional group of phenolic in curcumin (Naz et al, 2010; Sunilson et al, 2009; Rai et al, 2008; Cikrikci et al, 2008). Previous research have proven that diketopiperazine derivatives have antimicrobial activity (Santoso et al, 2011; Villemin and Alloum, 1990), oxytocin antagonist (Borthwick et al, 2009), cell growth inhibition, cytostatic, and cytotoxic (Andreani et al, 2008), anticancer of sporidesmins analogues (Polaske et al, 2009), antioxidant (Santoso and Supardjan, 2010), and antileishmanial in vitro in Leishmania donovani (Hazra et al, 2007). Santoso (2010) has done a molecular docking of diketopiperazine derivates on tubulin, the limiting factor in the cycle process of breast cancer in cell line T47D (Da'i et al, 2007). In that study also proves Vina enhanced molecular docking capabilities compared to AutoDock.

Vina is AutoDock-improved program that capable for molecular screening based on freeenergy and binding conformation prediction between ligand and protein target. AutoDock Vina program has multi-core capability, high performance, and enhanced accuracy than AutoDock (Trott and Olson, 2010). Based on the above description that the aim of these studies is to screen diketopiperazine derivates on dehydrosqualene synthase of $S$. aureus using Vina.

\section{MATERIAL AND METHODS}

Appliance: a computer with specifications: 1) the Gaussian-DFT calculations using Intel Core2Quad processor 2.4 GHz with 4GB RAM and 2) on molecular screening using intel i7 QuadCore processor 3.4 GHz with 8GB RAM.
Methods: Diketopiperazine geometry derivates,

optimization, curcumin analogues, curcumin, pentagammavunon derivates (PGV-0 and PGV-1) were calculated for their geometry optimization energy using Gaussian-Density Functional Theory method.

Reference ligands: a set of reference compounds obtained by screening an online database of the 3D-mimics database in the following procedure: target protein (crystal structure of dehydrosqualene synthase obtained from www.pdb.org) is uploaded into a database, amino acids (residue) of the binding site pocket were selected by referring to research of Bhatia et al (2010), then fingerprintbased filtering of shaped similarity scoring method was selected and submitted to obtain a maximum of 200 reference compounds. All downloadable reference compounds serve as inputs in next step of molecular screening using Vina.

Molecular screening procedure: all the selected compounds that has been 3Doptimized geometry along with the reference ligands were screened for their binding energy on dehydrosqualene synthase (2ZCO) by docking using Vina. This was done by loading all the compounds in the tab of openbabel in PyRx program and converted all files into an extension .pdbqt then execute Vina wizard with maximized screening grid box until the results of molecular docking obtained as binding energy in units of $\mathrm{kcal} / \mathrm{mol}$.

\section{RESULTS AND DISCUSSION}

\section{Geometry optimization}

Calculations have been carried out to obtain 3D molecular geometry structure in low energy conditions using DFT calculation method: B3LYP/6-31 $(\mathrm{g})$. The results of geometry optimization of diketopiperazine derivates and curcumin analogues showed that the compounds are in the top thirteen ligands (Figure 1). Two hundred geometry-optimized reference compounds were obtained but only 176 reference compounds were used in molecular docking because several reference compounds could not be converted to .pdbqt file. Although diketopiperazine derivates and curcumin analogues molecules were not test by 3D-structure alignment, as can be seen in Figure 1 the molecules have similar structures.

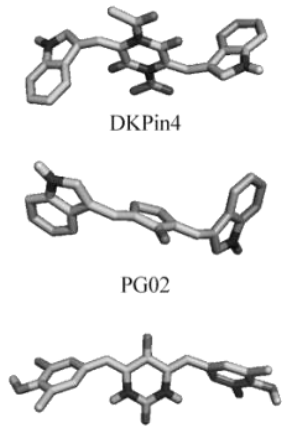

07038

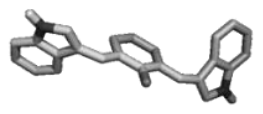

HG02

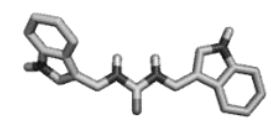

$0702 \mathrm{bR}$

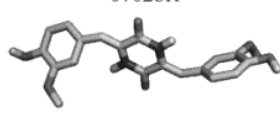

VAN-DKP

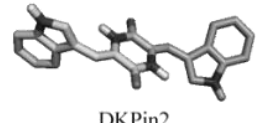

DKPin2

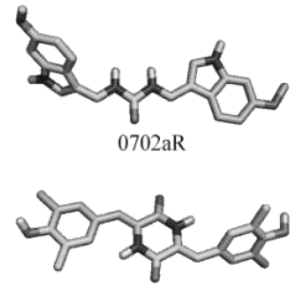

4OH-DKP

Figure 1- Structure of 3D-optimized geometry of top thirteen of diketopiperazine derivates except $4 \mathrm{OH}-\mathrm{DKP}$ and curcumin analogues using DFT:B3LYP/6-31(g) calculation (reproduced by PyMol) 


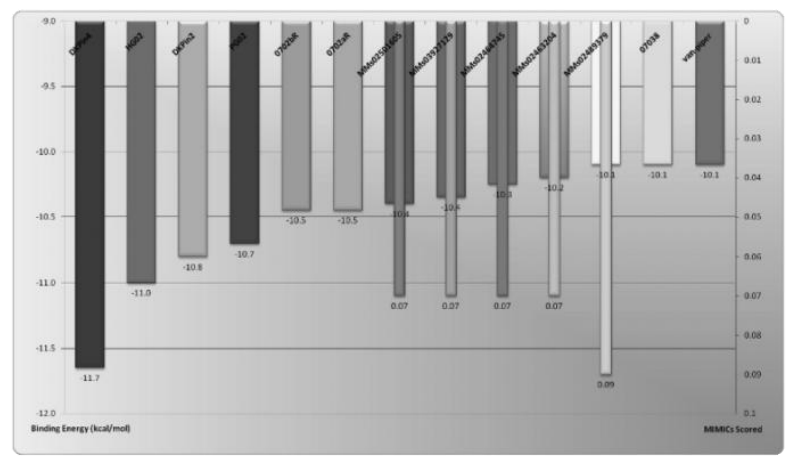

Figure 2- Docking binding energy $(\mathrm{kcal} / \mathrm{mol})$ of top thirteen 3D-molecular screening using Vina on Staphylococcus aureus dehydrosqualene synthase protein (2ZCO), diketopiperazine derivates = DKPin4, DKPin2, 07038 and van-piper (VANDKP); curcumin analogues = HG02, PG02, 0702bR, and 0702aR; others are reference compounds from 3D-MIMICs Database

Molecular screening diketopiperazin to be the strongest of all the compounds tested. derivatives VAN-DKP and 07038 has the highest binding

3D molecular screening has been done to the diketopiperazine derivates compared to curcumin analogues and reference compounds using PyRx Vina program. Average binding energy is shown in Figure 2. These results indicate that DKPin4 has the lowest binding energy with ligand-receptor binding is predicted energy but $2 \mathrm{ZCO}$ and $4 \mathrm{OH}-\mathrm{DKP}$ have higher binding energy than those compounds (data not shown). Ligand-receptor binding prediction of VAN-DKP is lower than DKPin4. VAN-DKP has antibacterial activity against $S$. aureus (unpublish research) and $4 \mathrm{OH}-\mathrm{DKP}$ has antibacterial

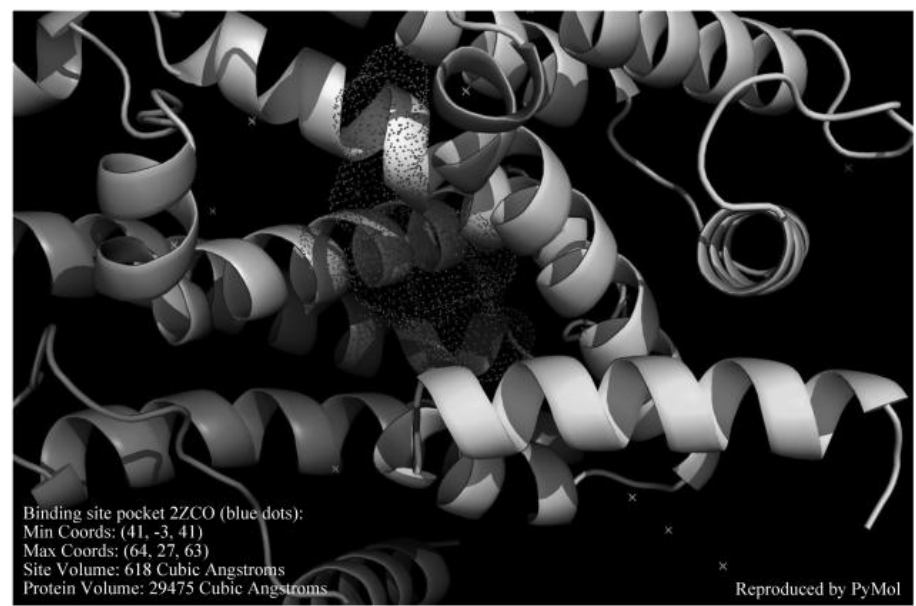

Figure 3- Result Q-SiteFinder online of dehydosqualene synthase (2ZCO) (Laurie and Jackson, 2005)

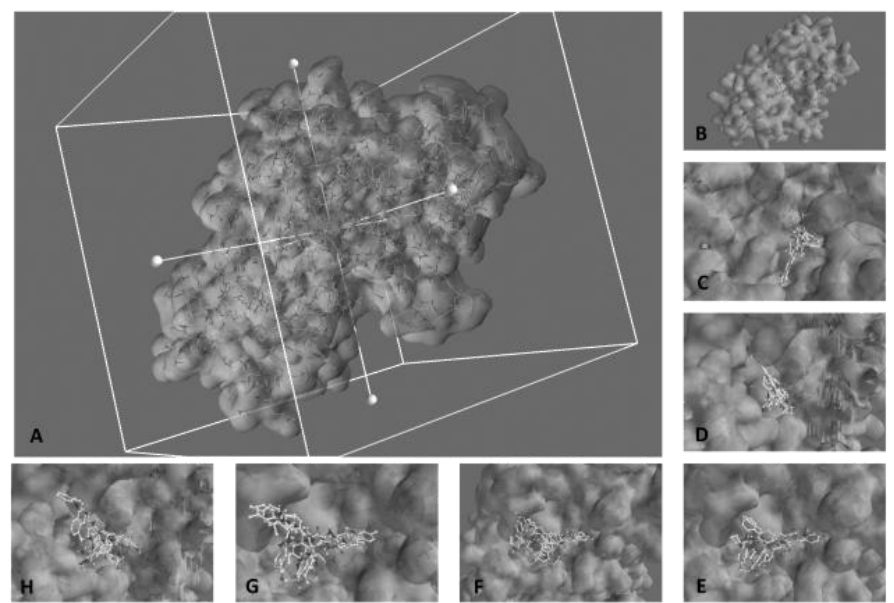

Figure 4- Molecular Docking Grid Box (A) and position of top thirty ligands (B) in protein target (2ZCO) using Vina (C, D, E, $\mathrm{F}, \mathrm{G}$, and $\mathrm{H}$ are group of five ligands from top to bottom of top thirty) 


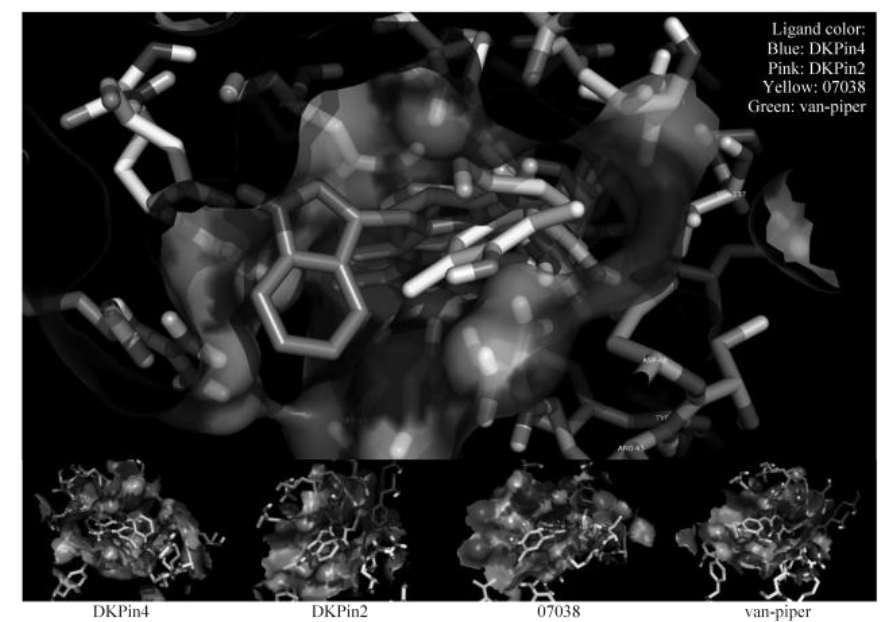

Figure 5- Binding site pocket of diketopiperazine derivates on 2ZCO (reproduced by PyMol)

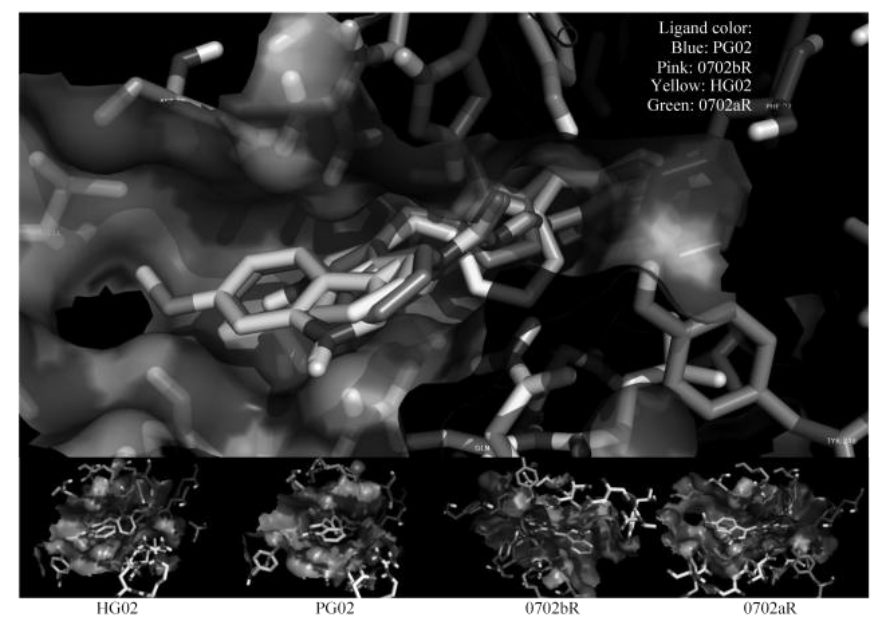

Figure 6- Binding site pocket of curcumin analogues on 2ZCO (reproduced by PyMol)

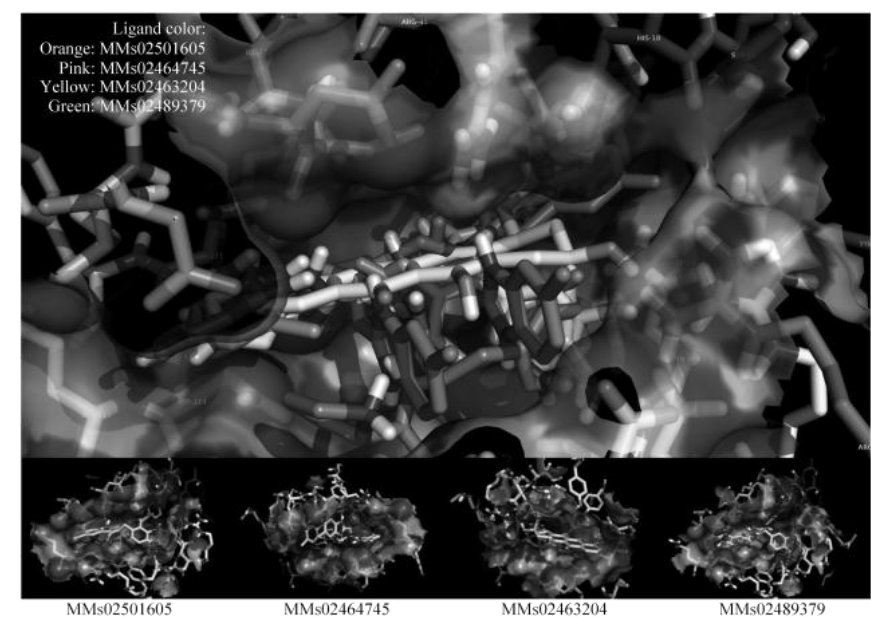

Figure 7- Binding site pocket of reference compounds on 2ZCO (reproduced by PyMol)

activity against Bacillus subtilis (Santoso et al, 2011). DKPin4 molecule is predicted to have antimicrobial activity better than VAN-DKP dan 4OH-DKP.

By using Q-Sitefinder online, dehydrosqualene synthase (2ZCO) has ten binding site pockets with the biggest volume site shown in Figure 3. Molecular docking is done by using a maximized grid box because crystal structure of dehydrosqualene synthase is not obtained in conjunction with specific ligands that can serve as a molecular template (Figure 4). Figure 5, 6, and 7 shows that the lowest energy binding of each compound group is obtained in the binding site pocket. These results are consistent with Bhatia et al (2010) research. 


\section{CONCLUSION}

Top thirteen ligands of docking binding energy with receptor are diketopiperazine derivates (31\%), curcumin analogues $(31 \%)$, and reference ligands (38\%). The new compounds of diketopiperazine derivates and curcumin analogues have better potency of binding energy than curcurmin as lead compound.

\section{REFERENCES}

Andreani, A., Burnelli, S., Massimiliano, G., Leoni, A., Locatelli, A., Morigi, R., Rambaldi, M., Varoli, L., Landi, L., Prata, C., Berridge, M. V., Grasso, C., Fiebig, H. H., Kelter, G., Burger, A.B., and Kunkel, M.W., 2008, Antitumor Activity of Bis-indole Derivates, J. Med. Chem., 51, 4563-4570.

Bhatia, M. S., Ingale, K. B., Choudhari, P. B., Zarekar, B. E., Bhatia, N. M., and Sherikar, A. S., 2010, 3D QSAR: Exploring Influence of Parameters of Pyrazoline Analogues on Resistant Strains of Staphylococcus aureus, International Journal of Drug Design and Discovery, 1, (1), 41-48.

Borthwick, A. D., Hatley, R. J., Hickey, D. M. B, Liddey, J., Livermore, D. G. H., Mason, A. M., Miller, N. D., Nerozzi, F., Sollis, S. L., Szardenings, A. K., and Wyatt, P. G, 2009, Substituted Diketopiperazines as Oxytocin Antagonists, United States Patent Application Publication, 12/ 412, 837.

Cikrikci, S., Mozioglu, E., and Yilmaz, H., 2008, Biological Activity of Curcuminoids Isolated from Curcuma longa, Rec. Nat. Prod., 2, (1), 19-24.

Da'i, M., Meiyanto, E., Supardjan, A. M., Jenie, U. A., and Kawaichi, M., 2007, Potensi Antiproliferative Analog Kurkumin Pentagammavunon terhadap Sel Kanker Payudara T47D, Artocarpus, 7, (1), 14-20.

Floris, M., Masciocchi, J., Fanton, M., and Moro, S., 2011, Swimming into Peptidomimetic Chemical Space using pepMMsMIMIC, Nucl. Acids Res., May, 1-9.

Frisch, M. J., et al, 2009, Gaussian 09, Revision A.02, Gaussian, Inc., Wallingford CT, ww.gaussian.com.

Hazra, A., Paira, P., Palit, P., Banerjee, S., Mondal, N. B., and Sahu, N. P., 2007, Synthesis of Symmetrically 1,4-disubstituted Piperazine-2,5-dions; New Class of Antileishmanial Agents, Journal of Chemical Research, 7, 381-383.

Laurie, A.T., and Jackson, R.M., 2005, Q-SiteFinder: an energy-based method for the prediction of protein-ligand binding sites, Bioinformatics, 21, 1908-1916.

Naz, S., Jabeen, S., llyas, S., Manzoor, F., Aslam, F., and Ali, A., 2010, Antibacterial Activity of Curcuma longa Varieties Against Different Strains of Bacteria, Pak. J. Bot., 42, (1), 455-462.

Parameshwar, K. S., Kumar, B. A., Reddy, A. S. and Parthasarathy, T., 2009, Quantitative Structure Activity Relationship (QSAR) Studies of Quinolone Derivatives as Potential Antibacterial Agents, Rasayan J. Chem., 2, (1), 247-250.

Polaske, N. W., Nichol G. S., Szabo L. Z., and Olenyuk B., 2009, Polymorphism and Phase Transition Behaviour of 6,6'-bis(chloromethyl)-1,1'4,4'-tetramethyl-3,3'-(phenylenedimethylene)bis(piperazine-2,5-dione), Acta Crystallographica Section C, 65, 8, 0381-0384.

Rai, D., Singh, J. K., Roy, N., and Panda, D., 2008, Curcumin Inhibits FtsZ Assembly: an Attractive Mechanism for its Antibacterial Activity, Biochem. J., 410, 147-155.

Santoso, B., Shani, Y. M., and Haryoto, 2011, Antibacterial Activity of 3,6-bis[(4-hydroxy-3methoxyphenyl)metiliden]piperazine-2,5-dione and 3,6-bis[(4-hydroxy-3,5dimethylphenyl)metiliden]piperazine-2,5-dione on Bacillus subtilis and Propionibacterium acne, Final Project Report, Faculty of Pharmacy, Muhammadiyah University of Surakarta. 
Santoso, B., and Supardjan, A.M., 2010, Radical Scavenging Activity of 3,6-bis[(4-hydroxy-3methoxyphenyl)metiliden]piperazine-2,5-dione dimethylphenyl)metiliden]piperazine-2,5-dione and

3,6-bis[(4-hydroxy-3,5on 2,2-diphenyl-1-picrylhydrazyl (DPPH), Proceeding, Seminar Nasional Eight Star Performance Pharmacist, Faculty of Pharmacy, Gadjah Mada University, Yogyakarta, December, $27^{\text {th }}$.

Santoso, B., 2010, Docking of Curcumin Analogues Piperazinedione Derivates on Tubulin (1TUB) Chain $\beta$ Using Vina and AutoDock, Proceeding, Kongres IImiah IAI ke-18, Makasar, December, $10^{\text {th }}$.

Sunilson, J. A. J, Suraj, R., Rejitha, G., Anandarajagopal, K., Kumari, A. V. A. G, and Promwichit, P., 2009, In vitro Antimicrobial Evaluation of Zingiber officinale, Curcuma longa and Alpinia galanga Extracts as Natural Food Preservatives, American Journal of Food Technology, 4 (5), 192-200.

The PyMOL Molecular Graphics System, Version 1.4.1, Schrödinger, LLC.

Trott, O., and Olson, A. J., 2010, AutoDock Vina: Improving The Speed and Accuracy of Docking with a New Scoring Function, Efficient Optimization and Multithreading, Journal of Computational Chemistry, 31, 455-461.

Villemin, D., and Alloum, A. B., 1990, Potassium Fluoride On Alumina: Condensation of 1,4Diacetylpiperazin-2,5-Dione with Aldehydes. Dry Condensation Under Microwave Irradiation. Synthesis of Albonursin and Analogues, Synthetic Communications, 20, (21), 3325-3331.

Wolf, L.K., 2009, New Software and Websites for the Chemical Enterprise, Chemical \& Engineering News, 87, 31. 